\title{
OPEN Author Correction: Quantitative vessel tortuosity: A potential CT imaging biomarker for distinguishing lung granulomas from adenocarcinomas
}

\author{
Mehdi Alilou, Mahdi Orooji, Niha Beig@, Prateek Prasanna, Prabhakar Rajiah, \\ Christopher Donatelli, Vamsidhar Velcheti, Sagar Rakshit, Michael Yang, Frank Jacono, \\ Robert Gilkeson, Philip Linden \& Anant Madabhushi
}

Correction to: Scientific Reports https://doi.org/10.1038/s41598-018-33473-0, published online 16 October 2018

This Article contains an error in the Discussion.

The text,

"Nearly all of the positive results were negative for cancer, producing a false-positive rate of $97.5 \%$ from radiologist based CT interpretations of the CT exams."

should read:

"Nearly all of the positive results were negative for cancer, producing a high proportion of false positives within the positive results (97.5\%) for lung cancer, from radiologist based CT interpretations of the CT exams."

\begin{abstract}
(c) (i) Open Access This article is licensed under a Creative Commons Attribution 4.0 International License, which permits use, sharing, adaptation, distribution and reproduction in any medium or format, as long as you give appropriate credit to the original author(s) and the source, provide a link to the Creative Commons license, and indicate if changes were made. The images or other third party material in this article are included in the article's Creative Commons license, unless indicated otherwise in a credit line to the material. If material is not included in the article's Creative Commons license and your intended use is not permitted by statutory regulation or exceeds the permitted use, you will need to obtain permission directly from the copyright holder. To view a copy of this license, visit http://creativecommons.org/licenses/by/4.0/.
\end{abstract}

(C) The Author(s) 2019 